\title{
PELAKSANAAN PEMBERIAN BANTUAN HUKUM KEPADA TERSANGKA ILLEGAL LOGGING DI KABUPATEN BLORA
}

\author{
Winar Dwi Pamungkas, Yusriyadi, Irawati \\ Program Studi Magister Kenotariatan \\ Fakultas Hukum, Universitas Diponegoro \\ Email :winardp16@gmail.com
}

\begin{abstract}
This article discusses legal assistance to disadvantaged people in the case of illegal logging that occurred on 17 February 2008 handled by Randublatung Sector Police at the investigation stage that occurred in Blora District. Providing legal assistance when investigating gives a sense of calm to the recipients of legal aid. This research uses an empirical juridical approach. This article aims to examine the process of traveling a program, as well as outlining the facts of how law works in society. This article also analyzes legal assistance to suspects in illegal logging in Blora district. The data analysis method used is qualitative analysis. From this article, it is known that the terms and procedures for providing legal assistance in illegal logging criminal cases in Blora Regency are in accordance with Law Number 16 of 2011 concerning Legal Aid, Government Regulation of the Republic of Indonesia Number 42 of 2013 concerning Terms and Procedures for Providing Legal Aid and Distribution of Legal Aid Funds and Government Regulation Number 83 of 2008 concerning Requirements and Procedures for Providing Legal Aid for Free.
\end{abstract}

Keywords : legal assistance; investigation; illegal logging

\begin{abstract}
Abstrak
Artikel ini membahas tentang bantuan hukum terhadap masyarakat tidak mampu pada kasus illegal logging yang terjadi pada tanggal 17 Februari 2008 ditangani oleh Polsek Randublatung di tahap penyidikan yang terjadi di Kabupaten Blora. Dilakukannya pemberian bantuan hukum pada saat penyidikan memberikan rasa lebih tenang kepada penerima bantuan hukum. Penelitian ini menggunakan metode pendekatan yuridis empiris. Artikel ini bertujuan untuk memeriksa proses perjalanan suatu program, sekaligus menguraikan fakta-fakta bagaimana bekerjanya hukum dalam masyarakat. Artikel ini juga menganalisis mengenai bantuan hukum kepada tersangka tindak pidana illegal logging di Kabupaten Blora. Metode analisis data yang digunakan adalah analisis kualitatif. Dari artikel ini diketahui bahwa syarat dan prosedur pemberian bantuan hukum dalam perkara pidana illegal logging di Kabupaten Blora sudah sesuai dengan Undang-undang Nomor 16 tahun 2011 tentang Bantuan Hukum, Peraturan Pemerintah Republik Indonesia Nomor 42 Tahun 2013 tentang Syarat dan Tata Cara Pemberian Bantuan Hukum dan Penyaluran Dana Bantuan Hukum dan Peraturan Pemerintah Nomor 83 Tahun 2008 tentang Persyaratan dan Tata Cara Pemberian Bantuan Hukum Secara Cuma-cuma.
\end{abstract}

\section{Kata kunci : bantuan hukum; penyidikan; illegal logging}

\section{A. Pendahuluan}

Bantuan hukum merupakan satu dari solusi untuk menyelesaikan masalah hukum, terutama dari segi pelaksanaan pemberian bantuan hukum oleh Lembaga Bantuan Hukum. Undang-undang Dasar Negara Republik Indonesia Tahun 1945 menjamin adanya persamaan dihadapan hukum, sebagaimana jelas tertuang dalam Pasal 27 ayat (1) Undang Undang Dasar 
1945 disebutkan bahwa "setiap warga Negara Indonesia bersamaan kedudukannya dalam hukum dan pemerintahan itu dengan tidak ada kecualinya”. Hakikat dari bantuan hukum yaitu bantuan hukum yang diberikan oleh para ahli bagi masyarakat yang memerlukan untuk mewujudkan hak-haknya dan mendapatkan perlindungan hukum yang wajar (Widyadharma, 2010).

Pada umunya, pengertian bantuan hukum memiliki ciri dalam istilah yang berbeda. Ada yang mengistilahkan sebgai legal aid, legal assistance, dan legal service. Legal aid diartikan sebagai pemberian jasa hukum secara cuma-cuma, kepada masyarakat tidak mampu dengan tujuan membela kepentingan dan hak-hak masyarakat miskin. Legal assistance, memiliki pemaknaan yang lebih luas dari legal aid, dimana bantuan hukum tidak hanya ditujukan kepada masyarakat miskin, tetapi juga juga kepada mereka yang mampu membayar prestasi. Sedangkan Legal service cenderung memiliki pengertian yang lebih luas dibandingkan legal aid dan legal assitance. Legal service dalam operasionalnya lebih cenderung untuk menyelesaikan setiap persengketaan dengan jalan menempuh jalan perdamaian (Harahap, 2014).

Masyarakat golongan menengah kebawah atau miskin mempunyai hak untuk menyelesaikan masalah hukum dan memperoleh suatu keadilan dengan disediakan bantuan hukum oleh Pemerintah Indonesia yang diatur dalam Pasal 1 ayat (1) Undang-undang Nomor 16 Tahun 2011 tentang Bantuan Hukum menyatakan bahwa "bantuan hukum adalah jasa hukum yang diberikan oleh pemberi bantuan hukum secara cuma-cuma kepada penerima bantuan hukum", selanjutnya Pasal 1 ayat (2) menyebutkan bahwa "penerima bantuan hukum adalah orang atau kelompok orang miskin”.

Ruang lingkup bantuan hukum, sebagaimana tertuang dalam Pasal 4 ayat (2) UndangUndang Nomor 16 Tahun 2011 disebutkan dengan jelas bahwa "bantuan hukum yang diberikan meliputi masalah hukum keperdataan, pidana, dan tata usaha negara baik litigasi maupun nonlitigasi”. Apabila masyarakat tidak mampu, melakukan tindak pidana mereka juga berhak menerima bantuan hukum, karena sudah dijelaskan dalam Pasal 56 ayat (1) Undang-undang Nomor 8 Tahun 1981 tentang Hukum Acara Pidanadijelaskan bahwa "dalam hal tersangka atau terdakwa disangka atau didakwa melakukan tindak pidana yang diancam dengan pidana mati atau ancaman pidana lima belas tahun atau lebih atau bagi mereka yang tidak mampu diancam yang dengan lima tahun atau lebih yang tidak mempunyai penasehat hukum sendiri, pejabat yang bersangkutan pada semua pemeriksaan dalam proses peradukan wajib menunjuk penasehat hukum bagi mereka.Selanjutnya dalam Pasal 56 ayat (2) Undang-undang Nomor 8 Tahun 1981 tentang Hukum Acara Pidana dijelaskan bahwa"setiap penasihat hukum yang 
ditunjuk untuk bertindak sebagaimana dimaksud dalam ayat (1), memberikan bantuannya dengan cuma-cuma".

Bantuan hukum harus mengacu pada hak asasi manusia, karena harus melindungi hakhak rakyat untuk mendapatkan bantuan hukum dan memperjuangkan kepentingan yang sah dan damai. Pelaksanaan pemberian bantuan hukum diberitahukan penyidik pada awal pemeriksaan sesuai dengan Pasal 114 Undang-undang Nomor 8 Tahun 1981 tentang Hukum Acara Pidana menjelaskan bahwa "seorang yang diduga telah melakukan tindak kejahatan, memiliki suatu hak yang harus di ketahui dan diberitahukan oleh penyidik sebelum dilakukannnya pemeriksaan oleh penyidik dan hak tersebut berupa bantuan hukum atau bahwa seorang yang diduga dalam perkaranya wajib didampingi seorang pengacara dalam Pasal 56 KUHAP”.

Indonesia sebagai negara hukum yang mengutamakan keadilan di atas segalanya dan menjunjung tinggi hak asasi manusia maka setiap masyarakat berhak untuk mendapat perlakuan yang sama dimata hukum dan aturan yang berlaku di Indonesia. Oleh karena itu, untuk setiap tindak kejahatan atau pelanggaran hukum yang dituduhkan, seorang yang di sangka berhak pula untuk mendapat bantuan hukum yang diperlukan sesuai dengan asas negara hukum. Asas dari negara hukum mengandung prinsip kedudukan yang sama dalam hukum atau sering disebut praduga tak bersalah.

Salah satu pemberian bantuan hukum terhadap masyarakat tidak mampu pernah terjadi pada tanggal 17 Februari 2008 ditangani oleh Polsek Randublatung dalam perkara tindak pidana illegal logging pada tahap penyidikan yang terjadi di Kabupaten Blora. Tindak pidana tersebut dimaksud dalam Pasal 50 ayat (3) huruf h Undang-undang Nomor 41 Tahun 1999 tentang Kehutanan. Mencermati dari penelitian sebelumnya, dapat dikatakan penelitian ini berbeda dengan penelitian tersebut, adapun unsur kebaruan dalam penelitian ini terletak pada subjek hukum, pokok masalah hukum, kajian isu hukum yang dalam kajian ini membahas syarat dan prosedur pemberian bantuan hukum pada tahap penyidikan.

Berdasarkan uraian dalam latar belakang tersebut, maka dalam penulisan ini akan mengkaji mengenai masalah yaitu mengenai Syarat Memperoleh Bantuan Hukum Dalam Perkara Tindak Pidana Berdasarkan Peraturan Mengenai Bantuan Hukum di Indonesia dan proses pemberian bantuan hukum perkara pidana ditahap penyidikan dalam kasus illegal logging di Kabupaten Blora.

Terdapat beberapa artikel dengan tema yang sama dengan artikel penulis yaitu artikel milik. Winarno di tahun 2013 dengan judul "Penegakkan Hukum Tindak Pidana Illegal Loging (Antara Harapan Dan Kenyataan). Artikel tersebut membahas mengenai bagaimana pelaksanaan penegakan hukum Illegal Logging di Indonesia? (Winarno, 2013). Selanjutnya 
artikel milik Andry Rahman Arifdi tahun 2015 dengan judul Pelaksanaan Pemberian Bantuan Hukum Terhadap Terdakwa Yang Tidak Mampu Dalam Perkara Pidana Di Kota Bandar Lampung. Artikel tersebut membahas mengenai Pelaksanaan Pemberian Bantuan Hukum terhadap Terdakwa yang Tidak Mampu dari Segi Ekonomi dalam Perkara Pidana, dan FaktorFaktor Penghambat Pelaksanaan Pemberian Bantuan Hukum terhadap Terdakwa yang Tidak Mampu dari Segi Ekonomi dalam Perkara Pidana (Arif, 2015). Kemudian artikel yang ditulis oleh Angga di tahun2019. Artikel tersebut membahas mengenai apa itu bantuan hukum, bagaimana cara mengajukan bantuan hukum, dan siapa saja yang bisa mendapat bantuan hukum secara cuma-cuma atau gratis (Angga, 2015).

Artikel ini memiliki perbedaan dengan beberapa artikel yang disebutkan di atas. Pada artikel ini lebih focus membahas mengenai bagaimana syarat mendapatkan bantuan hukum dalam perkara tindak pidana serta prosedur pemberian bantuan hukum perkara pidana ditahap penyidikan dalam kasus illegal logging di Kabupaten Blora.

\section{B. Metode Penelitian}

Artikel ini menggunakan metode penelitian yuridis empiris. Penelitian yuridis empiris sebagai bentuk penelitian yang bertujuan untuk memeriksa proses perjalanan suatu program, sekaligus menguraikan fakta-fakta bagaimana bekerjanya hukum dalam masyarakat. Artikel ini akan mengkaji secara teoritik berdasarkan Undang-undang dan peraturan-peraturan yang berlaku kemudian dihubungkan dengan apa yang terjadi di masyarakat. Di damping itu juga menganalisis mengenai bantuan hukum kepada tersangka tindak pidana illegal logging di kabupaten Blora. Artikel ini menggunakan data yang didapatkan dari bahan hukum primer dan akan dikaitkan dengan data yang didapatkan dari informan dan narasumber yang berkaitan dengan masalah dalam penelitian ini dan data sekunder didapatkan dari penelitian kepustakaan melalui bahan-bahan hukum seperti buku literatur. Dari hasil penelitian kepustakaan dan lapangan terkumpul kemudian akan dianalisa menggunakan metode analisis kualitatif untuk menjawab permasalahan dan akan digunakan penarikan kesimpulan secara induktif (Soekanto, 1984).

\section{Hasil Dan Pembahasan}

\section{Syarat Memperoleh Bantuan Hukum Dalam Perkara Tindak Pidana Berdasarkan Peraturan Mengenai Bantuan Hukum di Indonesia}

Bantuan hukum diatur dalam Pasal 54 Undang-undang Nomor 8 Tahun 1981 tentang Hukum Acara Pidana menjelaskan bahwa guna kepentingan pembelaan tersangka atau 
terdakwa berhak mendapatkan bantuan hukum dari seorang atau lebih penasehat hukum, selama waktu dan setiap tingkat pemeriksaan menurut tatacara yang ditentukan dalam Undang-Undang ini, selanjutnya dalam Pasal 56 Undang-undang Nomor 8 Tahun 1981 tentang Hukum Acara Pidana juga menjelaskan dalam hal seorang yang disangka melakukan tindak kejahatan yang diancam dengan pidana mati atau ancaman pidana lima belas tahun atau lebih atau bagi mereka yang memiliki ekonomi lemah atau dalam kategori kekurangan yang diancam dengan pidana lima tahun atau lebih yang tidak mempunyai pengacara sendiri, pejabat yang berkaitan pada semua tingkat pemeriksaan dalam proses peradilan wajib menunjuk pengacara bagi mereka.

Mengenai bantuan hukum dalam Pasal 114 Undang-undang Nomor 8 Tahun 1981 tentang Hukum Acara Pidana dijelaskan dalam hal seorang diduga melakukan suatu tindak kejahatan sebelum dimulainya pemeriksaan oleh petugas yang berwenang dalam proses penyidikan, petugas berwenang tersebut wajib memberitahukan haknya kepada orang yang diduga telah melakukan tindak kejahatn untuk mendapatkan bantuan hukum atau bahwa ia dalam perkaranya itu wajib didampingi oleh pengacara sebagai dimaksud dalam Pasal 56. Dan bantuan hukum dijelaskan lebih luas dalam Undang-undang Nomor 16 Tahun 2011 tentang Bantuan Hukum dan cara mendapatkan bantuan dalam perkara hukum juga dijelaskan dalam Pasal 14 dan 15 Undang-undang Nomor 16 Tahun 2011 tentang Bantuan Hukum menjelaskan mengenai syarat dan tata cara pemberian bantuan hukum mengenai mengajukkan permohonan bantuan hukum dan jawaban dari pemberi bantuan hukum paling lama 3 (tiga) hari kerja setelah permohonan bantuan hukum dinyatakan lengkap memberikan jawaban menerima atau menolak bantuan hukum dan ketentuan lebih diatur dalam Peraturan Pemerintah yaitu Peraturan Pemerintah Republik Indonesia Nomor 42 Tahun 2013 tentang Syarat dan Tata Cara Pemberian Bantuan Hukum dan Penyaluran Dana Bantuan Hukum.

Syarat dan tata cara pemberian bantuan hukum diatur dalam Peraturan Pemerintah Republik Indonesia Nomor 42 Tahun 2013 tentang Syarat dan Tata Cara Pemberian Bantuan Hukum dan Penyaluran Dana Bantuan Hukum, selanjutnya akan diuraikan dalam uraian sebagai berikut :

Berdasarkan Pasal 2 Peraturan Pemerintah Republik Indonesia Nomor 42 Tahun 2013 tentang Syarat dan Tata Cara Pemberian Bantuan Hukum dan Penyaluran Dana Bantuan Hukum, menyebutkan bahwa "bantuan hukum diberikan oleh pemberi bantuan hukum kepada penerima bantuan hukum". Dan syarat agar seseorang memperoleh bantuan hukum menurut Pasal 3 Peraturan Pemerintah Republik Indonesia Nomor 42 Tahun 2013 tentang Syarat dan Tata Cara Pemberian Bantuan Hukum dan Penyaluran Dana Bantuan Hukum 
penerima bantuan hukum untuk mendapatkan bantuan hukum maka harus mengajukan permohonan tertulis kepada pemberi bantuan hukum dengan memuat identitas pemohon bantuan hukum dan uraian singkat mengenai pokok persoalan yang dimintakan bantuan hukum, dan menyerahkan dokumen-dokumen perkara serta melampirkan kartu identitas berupa Kartu Tanda Penduduk (KTP) dan surat keterangan miskin dari kelurahan.

Selanjutnya Pasal 4 Peraturan Pemerintah Republik Indonesia Nomor 42 Tahun 2013 tentang Syarat dan Tata Cara Pemberian Bantuan Hukum dan Penyaluran Dana Bantuan Hukum menjelaskan mengenai pemberi bantuan hukum harus juga memenuhi persyaratan antara lain pemberi bantuan hukum harus berbadan hukum, terakreditasi, memiliki kantor atau sekertariat yang tetap, memiliki pengurus, dan memiliki program bantuan hukum.

Pasal 5 Peraturan Pemerintah Republik Indonesia Nomor 42 Tahun 2013 tentang Syarat dan Tata Cara Pemberian Bantuan Hukum dan Penyaluran Dana Bantuan Hukum meliputi masalah hukum keperdataaan, hukum pidana, dan hukum tata usaha negara. Pemberian bantuan hukum kepada masyarakat miskin secara cuma-cuma ini diselenggarakan oleh Menteri yang kemudian dilaksanakan oleh pemberi bantuan hukum.

Pasal 6, Pasal 7, Pasal 8, dan Pasal 9 Peraturan Pemerintah Republik Indonesia Nomor 42 Tahun 2013 tentang Syarat dan Tata Cara Pemberian Bantuan Hukum dan Penyaluran Dana Bantuan Hukum menjelaskan mengenai mengajukan permohonan tertulis kepada pemberi bantuan hukum dengan memuat identitas pemohon bantuan hukum dan uraian singkat mengenai pokok persoalan yang dimintakan bantuan hukum, dan menyerahkan dokumen-dokumen perkara serta melampirkan kartu identitas berupa Kartu Tanda Penduduk (KTP) dan surat keterangan miskin dari kelurahan dan apabila pemohon tidak memiliki persyaratan yang dimaksud dalam Pasal 6, Pasal 7, Pasal 8 pemberi bantuan hukum akan membantu dalam memperoleh persyaratan tersebut.

Pasal 10 Peraturan Pemerintah Republik Indonesia Nomor 42 Tahun 2013 tentang Syarat dan Tata Cara Pemberian Bantuan Hukum dan Penyaluran Dana Bantuan Hukum menjelaskan mengenai pemohon yang tidak mampu menyusun permohonan secara tertulis dapat mengajukan permohonan secara lisan dan permohonan lisan dituangkan dalam bentuk tulisan oleh pemberi bantuan hukum dan ditanda tangani atau dicap jempol oleh pemohon bantuan hukum.

Pasal 11 Peraturan Pemerintah Republik Indonesia Nomor 42 Tahun 2013 tentang Syarat dan Tata Cara Pemberian Bantuan Hukum dan Penyaluran Dana Bantuan Hukum menjelaskan pemberi bantuan hukum wajib memeriksa kelengkapan persyaratan pemohon bantuan hukum dan waktu paling lama dalam 1 (satu) hari kerja dan dalam hal permohonan 
telah memenuhi persyaratan pemberi bantuan wajib menyampaikan kesediaannya atau penolakannya paling lama 3 (tiga) hari kerja sejak permohonan dinyatakan lengkap.

Pasal 12 Peraturan Pemerintah Republik Indonesia Nomor 42 Tahun 2013 tentang Syarat dan Tata Cara Pemberian Bantuan Hukum dan Penyaluran Dana Bantuan Hukum menjelaskan pemberian bantuan hukum oleh pemberi bantuan hukum diberikan hingga masalahnya selesai dan mempunyai kekuatan hukum tetap selama penerima bantuan hukum tidak mencabut surat kuasanya.

Pasal 13, Pasal 14, Pasal 15 Peraturan Pemerintah Republik Indonesia Nomor 42 Tahun 2013 tentang Syarat dan Tata Cara Pemberian Bantuan Hukum dan Penyaluran Dana Bantuan Hukum menjelaskan tentang pemberian bantuan hukum yang dilakukan oleh advokat secara litigasi dengan cara pendampingan dan/atau menjalankan kuasa pada tingkat penyidikan, dan penuntutan atau pendampingan dan/atau menjalankan kuasa pada proses pemeriksaan di persidangan atau pendampingan dan/atau menjalankan kuasa terhadap penerima bantuan hukum di Pengadilan Tata Usaha Negara.

Pasal 16 Peraturan Pemerintah Republik Indonesia Nomor 42 Tahun 2013 tentang Syarat dan Tata Cara Pemberian Bantuan Hukum dan Penyaluran Dana Bantuan Hukum menjelaskan pemberian bantuan hukum secara nonlitigasi yang dapat dilakukan oleh advokat, paralegal, dosen, dan mahasiswa fakultas hukum dalam lingkup pemberi bantuan hukum yang telah lulus verifikasi dan akreditasi, bantuan nonlitigasi meliputi penyuluhan hukum, konsultasi hukum, investigasi perkara baik secara elektronik maupun non elektronik, penelitian hukum, mediasi, negoisasi, pemberdayaan masyarakat, pendampingan di luar pengadilan, dan drafting dokumen.

Pasal 17 Peraturan Pemerintah Republik Indonesia Nomor 42 Tahun 2013 tentang Syarat dan Tata Cara Pemberian Bantuan Hukum dan Penyaluran Dana Bantuan Hukum menjelaskan pemberian bantuan hukum harus memenuhi standar bantuan hukum yang ditetapkan dengan peraturan menteri.

\section{Prosedur Pemberian Bantuan Hukum Perkara Pidana Ditahap Penyidikan Dalam}

\section{Kasus Illegal Logging Di Kabupaten Blora}

Pembalakan atau (illegal loging) merupakan rangkaiana kegiatan dalam bidang kehutanan dalam rangka pemanfaatan dan pengelolaan hasil hutan kayu yang bertentangan dengan aturan hokum yang berlaku dana tau berpotensi merusak hutan. Dampak dari praktek illegal logging adalah perusakan hutan yang akan berdampak pada kerugian baik dari segi ekonomi ekologi maupun social budaya. Oleh karena kegiatan tersebut tidak melalui proses 
perencanaan yang komprehensif maka illegal logging mempunyai potensi merusak lingkungan (Marlina, 2018).

Pemberantasan illegal logging termasuk ke dalam kejahatan yang terorganisir. Ada actor intelektualnya, ada pelaku materialnya. Pelaku material bisa buruh penebang kayu yang hanya diupah, pemilik modal (cukong), pembeli, penjual dan acapkali ada backing dari oknum TNI atau Polri, aparat pemerintah maupun.

Terdapat faktor penyebab semakin maraknya illegal logging antara lain berasal dari keinginan untuk menguasai yang berlebihan. Factor tersebut yang menyebabkan factor umum yang menjaditerjadinya Illegal Logging di Indonesia (Zain, 2018).

Upaya yang dilakukan penyidik Polri untuk mengatasi kendala yang ditemui dalam pelaksanaan penyidikan antara lain, mengintensifkan koordinasi, pengawasan dan kegiatan patroli bersama dengan aparat terkait dikawasan yang tingkat Illegal Logging nya tinggi. Memberikan keyakinan dan perlindungan hukum kepada aparat penyidik PPNS maupun kepada masyarakat agar dapat berpatisipasi dengan aparat penyidik Polri dalam membantu pelaksanaan penyidikan tindak pidana Illegal Logging (Supriyadi, 2010).

Berdasarkan hasil wawancara dengan petugas yang berwenang dalam tahap Penyidikan Polsek Randublatung Brigadir Yoko, dapat diketahui mengenai proses penyidikan dalam kasus illegal logging dengan Nomor Perkara 8/Pid.B/2008/PN Bla di Kabupaten Blora. Terjadinya tindak pidana dilakukan pada tanggal 16 Februari 2008 saudara Kardi bin Jayus menebang satu batang pohon jati di hutan Sugih Turut Desa Bodeh, Kecamatan Randublatung, Kabupaten Blora. Kayu tersebut diangkut oleh Kardi bin Jayus dengan mengendarai 1 unit sepeda motor Yamaha Vega R dengan Nomor Polisi K 2274 FN, Nomor Rangka : MH33500016KO79589, Nomor Mesin 3S0080772, warna hijau. Sekitar pukul 16.00 WIB di jalan jurusan Jonggol Gembyungan tersangka bertemu petugas Perhutani dan kemudian tersangka Kardi bin Jayus berusaha melarikan diri, tetapi langsung tertangkap tangan dan diamankan di Polsek Randublatung.

Tertangkap tangan sebagaimana tertuang dalam Pasal 1 butir 19 Undang-undang Nomor 8 Tahun 1981 tentang Hukum Acara Pidana dijelaskan bahwa "tertangkap tangan adalah tertangkapnya seseorang pada waktu sedang melakukan tindak pidana atau dengan segera sesudah beberapa saat tindak pidana itu dilakukan, atau sesaat kemudian diserukan oleh kalayak ramai sebagai orang yang melakukannya atau apabila sesaat kemudian padanya ditemukan benda yang diduga keras telah dipergunakan untuk melakukan tindak pidana itu yang menunjukkan bahwa ia adalah pelaku tindak pidana itu yang menunjukkan bahwa ia adalah pelakunya atau turut melakukan atau membantu melakukan tindak pidana itu”. 
Pelaksanaan proses penyidikan berdasarkan Pasal 114 Undang-undang Nomor 8 Tahun 1981 tentang Hukum Acara Pidana bahwa "dalam hal seorang disangka melakukan tindak pidana sebelum dimulainya pemeriksaan oleh penyidik, penyidik wajib memberitahukan tersangka tentang haknya mendapatkan bantuan hukum atau wajib didampingi penasihat hukum pada kasus tertentu".

Diberikannya hak-hak tersangka sebagaimana terdapat dalam Pasal 56 Undangundang Nomor 8 Tahun 1981 tentang Hukum Acara Pidana bahwa "hak tersangka untuk memperoleh bantuan hukum dalam proses penyidikan, diberitahukan ancaman pidananya terlebih dahulu, yaitu apabila ancaman pidananya 5 tahun atau lebih dan tersangka merupakan orang yang kurang mampu, maka penyidik akan menyediakan bantuan hukum secara cuma-cuma"

Tersangka Kardi bin Jayus dilahirkan di Blora, pendidikan terakhir SD, pekerjaan tani, agama Islam, alamat Dukuh Butbanyu gang Kuntul, Desa Sambongwangan, Kecamatan Randublatung, Kabupaten Blora. Tersangka menyetujui untuk didampingi penasihat hukum dan diberikan bantuan hukum dan penyidik menunjuk ibu Maria Magdalena Kusdarini S.H. sebagai penasihat hukum. Tersangka memberikan kuasa untuk mendampinginya saat proses penyidikan kepada ibu Maria Magdalena Kusdarini S.H. Penyidikan dilakukan pada tanggal 18 Februari 2008 dan di dampingi oleh penasihat hukumnnya, tersangka ditangkap karena telah melakukan tindak pidana illegal logging di Kabupaten Blora, tersangka dikenakan Pasal 50 ayat (3) huruf h UURI Nomor 41 Tahun 1999 tentang Kehutanan.

Berdasarkan keterangan tersangka atau penerima bantuan hukum,bahwa pemberi bantuan hukum sudah menjalankan tugasnya sebagai seorang advokat, hal tersebut sesuai dengan Pasal 22 Undang-undang Republik Indonesia Nomor 18 Tahun 2003 tentang Advokat, yang menjelaskan advokat wajib memberikan bantuan hukum secara cuma-cuma kepada pencari keadilan yang tidak mampu.

Selanjutnya juga diatur lebih lanjut dengan Peraturan Pemerintah Nomor 83 Tahun 2008 tentang Persyaratan dan Tata Cara Pemberian Bantuan Hukum Secara Cuma-Cuma dalam Pasal 2 menjelaskan advokat wajib memberikan bantuan hukum secara cuma-cuma kepada pencari keadilan yang dimaksud masyarakat tidak mampu dan dalam Pasal 12 menjelaskan dilarang menolak permohonan bantuan hukum secara cuma-cuma yang berarti bahwa seorang profesi advokat memilik kewajiban untuk memberikan bantuan hukum kepada masyarakat yang tidak mampu. 


\section{Simpulan}

Syarat mendapatkan bantuan hukum dalam perkara tindak pidana illegal logging pada tahap penyidikan yang terjadi di Kabupaten Blora sudah sesuai dengan Peraturan Pemerintah Republik Indonesia Nomor 42 Tahun 2013 tentang Syarat dan Tata Cara Pemberian Bantuan Hukum dan Penyaluran Dana Bantuan Hukum, adapaun syarat dan prosedur tersebut yaitu : a. Pemohon bantuan hukum mengajukan permohonan bantuan hukum secara tertulis kepada pemberi bantuan hukum, dengan memuat identitas pemohon bantuan hukum dan uraian singkat mengenai pokok persoalan yang dimintakan bantuan hukum;dan b. melampirkan surat keterangan miskin dari Lurah/Kepala Desa/pejabat setingkat di tempat tinggal pemohon bantuan hukum; dan dokumen yang berkenaan dengan perkara;

Pemberian bantuan hukum kepada tersangka illegal logging di Kabupaten Blora, diberikan oleh advokat, yang ditunjuk dalam hal ini penasihat hukum bertindak secara pasif dalam penyidikan dengan dasar Pasal 115 KUHAP yang menjelaskan dalam hal penyidik sedang melakukan pemeriksaan terhadap tersangka, penasihat hukum dapat mengikuti jalannya pemeriksaan dengan cara melihat serta mendengar pemeriksaan fungsi dari pendampingan pada tahap penyidikan tersangka. Dari segi psikologis kehadiran penasihat hukum dalam pemeriksaan, mendorong tersangka lebih berani mengemukakan kebenaran yang dimiliki dan diketahuinya dan merasa lebih tenang dan aman.

\section{DAFTAR PUSTAKA}

\section{Buku}

Arikunto, Suharsimi. (2002). Prosedur Penelitian Suatu Pendekatan Praktek. Jakarta: Rineka Cipta. Harahap, M. Yahya. (2014). Pembahasan Permasalahan dan Penerapan KUHAP, Penyidik dan Penuntutan. Jakarta: Sinar Grafik.

Nazir, Moch. (2008). Metode Penelitian. Jakarta: Ghalia Indonesia.

Soekanto, Soekanto. (1984). Pengantar Penelitian Hukum. cet. 2007. Jakarta: UI Press.

Soemitro, R. Hanitijo. (1990). Metode Penelitian Hukum dan Jurimetri. Jakarta: Ghalia Indonesia.

Supriadi. (2010). Hukum Kehutanan \& Hukum Perkebunan di Indonesia. Jakarta. Sinar Grafika.

Zain, Alam Setia. (2000). Hukum Lingkungan Konservasi Hutan dan Segi- segi Pidana. Jakarta : PT. Rineka Cipta: Jakarta.

Widyadara, IGN. Ridwan. (2010). Profesional Hukum Dalam Pemberian Bantuan Hukum. Semarang: Badan Penerbit Universitas Diponegoro.

\section{Artikel Jurnal}

Andry, Rahman Arif. (2015). Pelaksanaan Pemberian Bantuan Hukum Terhadap Terdakwa Yang 
Tidak Mampu Dalam Perkara Pidana Di Kota Bandar Lampung. Fiat Justicia Jurnal Ilmu HUkum, Vol. 9 No. 1.

Angga dan Ridwan, Arifin. (2019). Penerapan Bantuan Hukum Bagi Masyarakat Kurang Mampu Di Indonesia. Diversi Jurnal Hukum, Vol. 4 No. 2.

Pelaksanaan Pemberian Bantuan Hukum Terhadap Terdakwa Yang Tidak Mampu Dalam Perkara

Pidana Di Kota Bandar Lampung. Fiat Justicia Jurnal Ilmu HUkum, Vol. 9 No. 1.

Marlina. (2018). Analisa Yuridis Penyidikan Tindak Pidana Illegal Logging oleh Polres Tapanuli Tengah. Mercatoria. Vol. 11 No. 1

\section{Undang-undang dan Peraturan}

Undang-undang Dasar Negara Republik Indonesia Tahun 1945.

Undang-undang Nomor 16 Tahun 2011 tentang Bantuan Hukum.

Undang-undang Nomor 41 Tahun 1999 tentang Kehutanan.

Undang-undang Nomor 8 Tahun 1981 tentang Hukum Acara Pidana.

Peraturan Pemerintah Republik Indonesia Nomor 42 Tahun 2013 tentang Syarat dan Tata Cara Pemberian Bantuan Hukum dan Penyaluran Dana Bantuan Hukum. 